\title{
The Effect of Rain-Fed and Supplementary Irrigation on the Yield and Yield Components of Maize in Mekelle, Ethiopia. \\ *Bello. W. B.
}

\begin{abstract}
The effect of rain-fed with rain-fed supplementary irrigation on yield and yield components of Maize (Zea mays L.) was carried out at Mekelle University main campus under Tigray region in Ethiopia. The experiment was laid out in a Randomized Complete Block Design (RCBD), and investigated in the early cropping season of the year 2007. There were two main treatments (Rain-fed (R1) and Rain-fed with supplementary irrigation (R2)). The R2 was irrigated three day interval after seedling at 110litre/plot. Fertilizer was applied to each plot at the rate of $180 \mathrm{~kg}$ Dap/plot and 30gramUrea/plot. All management practices were the same with exception of water added to R2. Data were analyzed for variance and LSD at 5\% level of significance. Result showed significant response on soil moisture content, harvested plant stand with number of cobs, fresh grain weight (kg) and dry grain weight $(\mathrm{kg})$ while other parameters (plant height, number of rows with cobs, number of seed/cob and 1000 fresh and grain weight (kg)), shown non-significant difference. The significant effect on harvested plant stand with cobs number indicated that the use of supplementary irrigation is essential for maize production in arid environment. However, there is need to re-investigate the same experiment during the late cropping season to strengthening water use efficiency of the crop and minimize the effect of climate impact.
\end{abstract}

Key words: Maize, Rain-fed, Rain-fed supplementary irrigation, water use efficiency, yield.

\section{Introduction}

$\mathrm{n}$ the drier farming regions of the
world, mainly with arid environments, crop production is heavily dependent on irrigation practice. Agricultural irrigation uses over $70 \%$ of the world's supplies of developed water.

Agricultural production is facing increased competition for limited water resources and it is expected to increase with the number of water deficit countries, population pressure and intensification tending towards desertification of most land. The efficiency of utilization of irrigation water is often low and around $50 \%$ of the increase in demand for water could be met by increasing the effectiveness of irrigation (Seckler et al., 1998). It is, therefore, important to improve the efficiency of water use and this can be done by approaching the economic maximum of plant material that will ensures high water use efficiency.

Water use efficiency nowadays is less improved hence, Mintesinot et al.; (2004) viewed that promoting its efficiency demands an urgent attention for improving productivity in dry environment. One of the methods for increasing water use efficiency is the adoption of cultural practices that will enhance production per unit of water. This can be achieved by crop-environment matching and by supplementing the cultural practice with irrigation. Water use efficiency is highly dependent on plant nutrient and, supply therefore, any plant input factor that increases economic yield will improve the water use efficiency (Davis, 1994). Moreover, Tesfaye (2004) viewed that water shortage for crop production is not only the result of water scarcity but also of mismatches between the resources availability and demand. Water use efficiency is a major factor for identifying the best irrigation scheduling strategies for supplemental irrigation (Pereira, et al.; 2002). Hence, irrigation if well targeted might solve part of food security problem, which is the main goal for improving water use efficiency.

According to Tesfaye (2005), the yearly water loss that is drained from Tigray region to neighboring Countries alone is estimated to be 9 billion cubic meters. This gives a big difference between the maize cultivated in rain fed fields and maize cultivated in irrigated fields in the region generally. Rain fed maize is the main livelihood, sometimes supported by traditional water harvesting methods in most dry region of the world. Pandey (2000) also viewed that the application of nitrogen fertilizer will improve the water productivity of a well nourished plant by actively maximizing its photosynthetic activity. In-line with this, many

*Department of Dry-land Crop and Horticultural Sciences, Faculty of Dry-land Agriculture and Natural Resources, Mekelle University, Ethiopia.- waswarith@yahoo.com 
The effect of Rain-fed...........Bello W.B

researchers has shown that the return from nitrogen can be increased by irrigation (Yadav et al.; 1998 and Ignazi 1992). To this end, Kang et al.; (2000) further concluded that irrigation, evaporation losses reduction, evenly distribution of roots and enhancement of roots development when applied on farm will result in a higher nutrient uptake and higher water productivity.

Maize (Zea mays L.; Poacceae) is the most important cereal after wheat and rice with regards to cultivation area (Osagie and Eka, 1998). In Ethiopia, it is one of the major staple crops ranking first in yield potential per hectare, and fourth in total area after teff (Eragrostis tef), barley and sorghum and this was why Banti et al.( 1997), explained that the annual production and productivity of maize exceeded all other crops grown in Ethiopia with the exception of teff in terms of area coverage. In developing countries, one of the main uses of maize is for food. However, in Africa especially in the eastern and southern regions; it is the dominant food crop and the mainstay of rural diets (Morris, 1998).

Maize water requirement vary more than the temperature needs. The crop is an efficient user of water in terms of total dry matter production. Also, the crop factor $(\mathrm{kc})$ relating to crop water requirements (Etc) with reference to evapo-transpiration (Eto) differs between growth stages (Cakir, 2004). The concern on the occurrence of actual crop water stress (deficit of plant accessible soil water) and the limiting of crop water stress (i.e. in which growth stages of the crop most likely to suffer from stress) demands an urgent attention. The phonological stage when water stress occurs determines the reduction level for the yield.

Therefore, the knowledge of the growing environment, climate and soil type, and the crop inherent behavior is crucial for the production and the assessment of the plant's water use. Kang et al (2000) further stated that the continuous water deficit during the flowering and the yield formation period determines the optimum irrigation method for maize production in the semi-arid areas. More so, two major factors determining the upper limit of the potential yield of maize have been identified as amount of moisture available during the growing season and the length of the growing season. Maximum yield can be
EJESM Vol.1 no.2 2008

realized when maize utilize a high percentage of the available solar energy (Tollenear, 1985).

This project, therefore, explores the effect of rainfed and rainfed with supplementary irrigation on maize yield and yield components as a means to sustainable maize production in arid environment.

\section{Materials and Methods}

The experiment was carried out at Mekelle University main campus, Tigray region, Ethiopia. Mekelle is located on longitude $13^{0} 30^{1} \mathrm{~N}$ and latitude $39^{0} 29^{1} \mathrm{E}$ at altitude ranging from $2100-2600 \mathrm{~m}$ above sea level (Solomon, 2001). The annual rainfall shows a high degree of variation with a coefficient ranging from $20 \%$ in the western to $49 \%$ in the eastern parts of the region (Barron et al.; 2003). The average annual rainfall amount in Mekelle is around $600 \mathrm{~mm}$. The pattern of rainfall is unimodal and about 60$84 \%$ of the total rainfall is received within four months (June-September). The spatial distribution is influenced by topography (Tesfaye and Walker, 2004).The soil is mainly deep cambisols derived from high vegetation cover and influenced by flat topography (Atakure, 2001).

The field experiment was carried out during the early cropping seasons (June September) but span to December, 2007. The test crop was Maize (Zea mays L. Var. ACV3) which was obtained from Hawassa Research Centre in Ethiopia. The field was ploughed and harrowed before laying out the plots. The plots were laid out in a Randomized Complete Block Design (RCBD). The main plot was $4.5 * 4.0 \mathrm{~m}$ while the sub plots were separated by $0.5 \mathrm{~m}$ apart. The main plots include two treatments (Rain fed (R1) and Rain fed with supplementary irrigation (R2)) and with three replications each (M1, M2 and M3) respectively. R2 was irrigated at three days interval after seedlings at 110 litre/ plot. Sowing on the plot was done on the same day. All management practices were the same with the exception of water which was applied to R2 as supplementary irrigation while R1 was mainly rain fed. Fertilizer was applied to each plot at the rate of 180 gram Dap/plot and 30gram Urea/plot. 
Data on grain yield at harvest were obtained from the plant in net rows. Measurements of plant height (PLH), leaf area (LA), and cob length were taken. Other parameters taken includes, the soil moisture content, Number of cobs per plant, Number of rows per plant, and weight taken includes fresh weight of the plants, dry weight of the plants, fresh grain yield, dry grain yield, weight of 1000 fresh and dry weight of seeds were also taken. Data collected were subjected to analysis of variance (Gomez and Gomez, 1984) and least significant difference (LSD) at $5 \%$ levels of significance was also used to test significant difference between treatments.

\section{Result and Discussion}

Table 1 shows the average rainfall, temperature and the relative humidity of the cropping months. There was more precipitation with high rainfall and lower temperature during the growing period. This observed trend in weather result may affect water use efficiency with reduction in evapotranspiration loss and this in turn affect the development of crops.

Rain fed maize significantly differed from supplementary rain fed irrigation on soil moisture content, harvested plant stand with number of cobs, fresh grain weight with dry grain weight $(\mathrm{kg})$ while other parameters were non-significant. Fig I and Table 2 (a, b and c) shows the relationship between average soil moisture content (gm) in Oct. 29, Nov. 19 and Dec 10 for both Rain fed and Rain fed with supplementary irrigation. Rain fed significantly differed from Rain fed with supplementary irrigation on all days observed. This is in line with the assertion of Sing et al.; (2002) that depth, extent of root system, size and total area of leaves, number and location of stomata, shoot growth and vigour of Maize are affected by rainfall or water availability.

The effect of Rain fed with supplementary rain fed irrigation on yield components is shown in Table 3 (Harvested plant stand and number of cobs and Table 4fresh grain weight with its dry grain weight $(\mathrm{kg})$. The added water significantly $(\mathrm{p}=0.5)$ increased the parameters measure in Table 3 and 4 on result over Rain fed. Significant effect on fresh grain weight with dry weight $(\mathrm{kg})$ and harvested plant stand with number of cobs further confirms that different levels of moisture content on planting area influenced the available nutrient to the crops. However, the non-significant of some parameter identified may be due to weather effects that exist during the growing period (high humidity, cloud-cover and low evaporation). The significant effect on harvested plant stand indicated that supplementary irrigation or water has a great effect on Maize yield production. This result further confirms Rathor (2005), result that continuous, heavy rains and subsequent water stressed conditions are abnormal conditions for Maize growth which affects its yield adversely.

However, the main use of Maize in Ethiopia is food, and hence, significant result of supplementary rain fed irrigation on grain weight and harvested plant stand with its cobs confirms the need for high water supply for Maize production in arid region.

\section{Conclusion}

Significant effect is usually expected in the use of irrigation water and rainfall in crop production during cultivation. The effect on moisture content, improvement effect on fresh grain weight and its dry grain weight and harvested plant stand with number of cobs suggested that the use of supplementary irrigation would aid Maize production. Considering the effects of water in photosynthesis, and different growth stages, there were significant impact of additional supply of water and this can be enhanced in dry season when the evapo-transpiration rate is high and a signal to water use-efficiency. The effect can further be observed in dry season to reduce drought on crops for high productivity. It is, therefore, suggested that optimum production of Maize could be realized with rain fed supplementary irrigation. Late season cropping of Maize should be encouraged with irrigation as a means to reduce drought in case of rain failure and sustainability of Maize production in arid environment. 


\section{References}

Atakure,A.; (2001). Soil survey in Mekelle University technical report. Mekelle University, Tigray region Ethiopia 32-36.

Barron, J.; Rockstrom, J.; Gichuki, F.and Hatibut, N.; (2003). Dry spell analysis and Maize yields for two semi-arid locations in East Africa. Agricultural and forest Meteorology, vol.117pp 23-37.

Benti, T.; Kebede, M.; Legesse, W.; Mosisa, W. and Leta, T.; (1997). Reflections on the successful achievements of hybrid maize breeding program in Ethiopia. pp67-71.In Ransom, J.K.; Palmer A.F.; Zambezi, B.T.; Muduruma., Z.O.;Waddigton,S.R .;Pixley, K.V.; Jewell D.C.(eds). Maize productivity gains through research and technology dissemination. Proceedings of the fifth Eastern and Southern Africa Regional Maize Conference, Arusha, Tanzania, June 3-7, 1996 ClIMMIYT, Addis Ababa, Ethiopia.

Cakir,R.; (2004). Effects of water stress at different developmental stages on vegetative and reproductive growth of Corn, field crops Research vol.89 pp1-6.

Davis,J.G.; (1994). Managing plant nutrients for optimum water use efficiency and water conservation. Advances in Agronomy S3: pp 85-120.

Gomez, K.N. and Gomez, A.A.(1984).Statistical procedures for Agricultural Research. John Wiley and Sons. Inc.; New York, $2^{\text {nd }}$ ed. p68.

Ignazi, J.C.; (1992). Improving nitrogen management in irrigated intensively cultivated areas.The approach in France Expert consultation on the prevention of water pollution by agriculture and related activities. Sanitago, Chile, October, 1992.

Kang, S.; Liang, Pen Z.; Ship, Y. and Zhang, J. (2000). Alternative furrow irrigation for Maize production in an arid area.. Agricultural water management,vol.45: 267- 274.

Mintesinot, B .; Verplancke, H.; Van Ranst, E. and Mitiku, H.; (2004). Examining Traditional irrigation methods, irrigation Scheduling and alternate furrows irrigation on Vertisols in northern Ethiopia. Agricultural water management, vol. 64: pp 17-27.
Morris, M.L. (1998) Overview of the World Maize Economy, in : Morris M.L, (ed) Maize seed Industries in Developing Countries Lynne Rienner Publisher, UK, pp 13-34

Osagie, A.U. and Eka, O.U.; (eds). (1998). Nutritional quality of plant foods post harvest research unit, University of Benin. pp. 34-41.

Pandey, R.K.; Maranville, J.W. and Chetima, M.M.; (2000). Deficit irrigation and nitrogen effects in Maize in Sahelian environmental II: Shoot growth, nitrogen up-take and water extraction. Agricultural water management vol. 46:15-27.

Pereira, L.S.; Oweis, T. and Zairi, A. (2002). Irrigation management under water scarcity. Agricultural water management; 57: pp 175206.

Rathor, P.S.; (2005). Techniques and management of field crop production. India: Agro-bios.524-536.

Seckler, D.; Amerasinghe U.; Molden D.; de Silva R. And Barker R.; (1998). World water demand and supply, 1990 to 2025: Scenarios and Issues. International Water Management Institute, Colombo, Sri Lanka

Singh, N.P. and Singh, R.A.; (2002). Scientific crop production. India Kalyeni: pp456-462.

Solomon, T.; (2001). Site survey in Mekelle University technical report. Mekelle University, Tigray region Ethiopia.24-28.

Tesfaye,G.; Mitiku, H.; G/medhin, B.; Pender, J. and Yazew, E.; (2005). Small scale irrigation in Tigray; Management and institutional considerations.

Tesfaye, K. and Walker, S.; (2004). Matching of crop and environment for optimal water use: Case of Ethiopia. Physics and Chemistry of the Earth,vol.29: pp1061-1067.

Tollenear, M.; (1985). What is the current upper limit of maize productivity? Agric, Res, Pot, Phosphate Institution, pp67-173.

Woldeab, T.; (2003). Irrigation Practices, state intervention and farmers' life- Worlds in drought-prone Tigray, Ethiopia. Ph.D Thesis. Wageingen, Netherlands.

Yadav, J.S.P; Kumar, A.S. and Kumar R.;(1998). Water and nutrient management in sustainable agriculture. Fertilizer News. December. 1998. FaI., New Delhi. 
Table.1:- Average rainfall, temperature and relative humidity during the growing period of Maize in 2007.

\begin{tabular}{|l|l|l|l|r|}
\hline \multirow{2}{*}{ Month } & \multicolumn{2}{|l|}{ Average Temperature (0C) } & \multirow{2}{*}{ Average RH \% } & Total Rainfall(mm) \\
\cline { 2 - 5 } & Min & Max & 85 & 37.50 \\
\hline June & 13 & 27 & 82 & 267.00 \\
\hline July & 14 & 25 & 81 & 147.50 \\
\hline August & 14 & 24 & 60 & 74.00 \\
\hline September & 12 & 25 & 55 & 0.00 \\
\hline October & 15 & 25 & 50 & 0.00 \\
\hline November & 15.5 & 25.5 & 50 & 0.00 \\
\hline December & 15 & 25.5 & & \\
\hline & & & & \\
\hline
\end{tabular}

Table 2(a, b c and d):- Result of soil moisture content.

Table 2a:- Soil moisture content taken on October 29, 2007.

\begin{tabular}{|l|c|c|c|c|c|c|}
\hline & \multicolumn{3}{|c|}{ Rain fed (R1) } & \multicolumn{2}{c|}{ Supplementary Irrigation (R2) } \\
\hline $\begin{array}{l}\text { Plot } \\
\text { no.(cm) }\end{array}$ & m1R1 & m2R1 & m3R1 & m1R2 & m2R2 & m3R2 \\
\hline $0-20$ & 15.2 & 15.4 & 19.6 & 35.9 & 41.8 & 30.3 \\
\hline $20-40$ & 18.1 & 19.6 & 20.3 & 28.1 & 34.5 & 30.8 \\
\hline $40-60$ & 13.2 & 22.9 & 19.3 & 27.6 & 32.8 & 25.1 \\
\hline
\end{tabular}

Table2b:- Soil moisture result taken on November 19, 2007.

\begin{tabular}{|c|c|c|c|c|c|c|}
\hline & \multicolumn{3}{|c|}{ Rain fed (R1) } & \multicolumn{3}{c|}{ Supplementary Irrigation (R2) } \\
\hline $\begin{array}{c}\text { Plot } \\
\text { no.(cm) }\end{array}$ & m1R1 & m2R1 & m3R1 & m1R2 & m2R2 & m3R2 \\
\hline $0-20$ & 16.40 & 15.20 & 13.70 & 25.00 & 25.30 & 26.00 \\
\hline $20-40$ & 17.10 & 13.90 & 15.70 & 23.40 & 25.20 & 27.10 \\
\hline $40-60$ & 18.10 & 10.70 & 16.40 & 23.40 & 31.00 & 25.10 \\
\hline
\end{tabular}

Table2c:- Soil moisture result taken on December 10, 2007.

\begin{tabular}{|c|c|c|c|c|c|c|}
\hline & \multicolumn{3}{|c|}{ Rain fed (R1) } & \multicolumn{3}{c|}{$\begin{array}{c}\text { Supplementary Irrigation } \\
\text { (R2) }\end{array}$} \\
\hline $\begin{array}{c}\text { Plot } \\
\text { no.(cm) }\end{array}$ & m1R1 & m2R1 & m3R1 & m1R2 & m2R2 & m3R2 \\
\hline $0-20$ & 8.30 & 6.90 & 13.50 & 20.30 & 16.10 & 18.00 \\
\hline $20-40$ & 10.50 & 12.90 & 16.10 & 15.70 & 15.40 & 19.60 \\
\hline $40-60$ & 14.50 & 13.10 & 16.40 & 19.90 & 16.20 & 20.90 \\
\hline
\end{tabular}


Table 2d- Average Soil moisture content for both treatments for the months of October, November and December

\begin{tabular}{|l|r|r|}
\hline & Rain fed (R1) & $\begin{array}{l}\text { Supplementary } \\
\text { Irrigation (R2) }\end{array}$ \\
\hline October & 18.17 & 31.88 \\
\hline November & 15.24 & 26.11 \\
\hline December & 12.47 & 18.01 \\
\hline
\end{tabular}

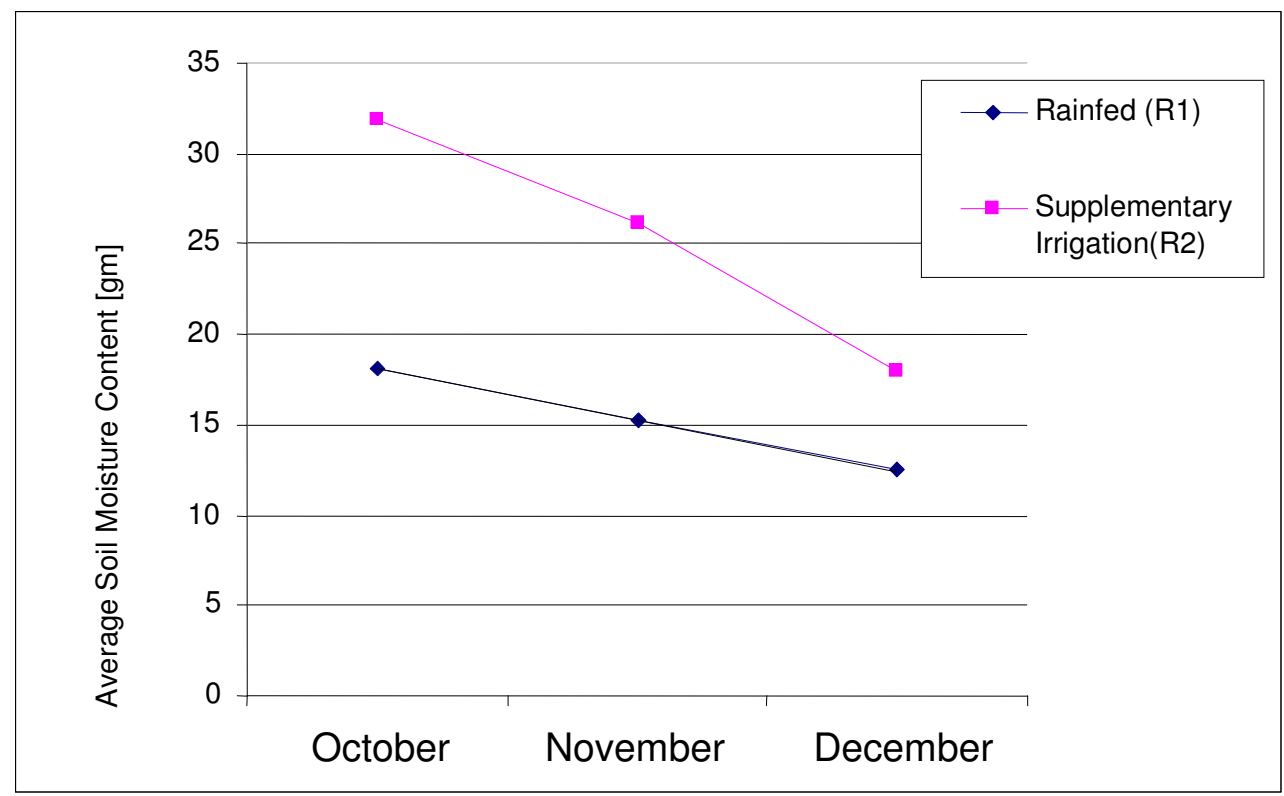

Figure 1 : Graph of $R 1$ and $R 2$ moisture content of the soil with time.

From the graph moisture content $R 1$ and $R 2$ decrease across time interval and shows substantial difference between rain fed and supplementary irrigation in all plots examined across time interval. 
Table 3:- Results of harvested plant stand and number of cobs (kg).

\begin{tabular}{|c|c|c|}
\hline Treatment & $\begin{array}{l}\text { Means of } \\
\text { harvested plant } \\
\text { stand }\end{array}$ & $\begin{array}{l}\text { Number of } \\
\text { cobs }\end{array}$ \\
\hline R1 & 30.67 & 32.00 \\
\hline R2 & 35.67 & 47.33 \\
\hline LSD(5\%) & 4.30 & 12.25 \\
\hline CV & $3.69 \%$ & $6.51 \%$ \\
\hline
\end{tabular}

Table 4:- Results of fresh grain weight and dry grain weight $(\mathrm{kg})$.

\begin{tabular}{|c|c|c|}
\hline & \multicolumn{2}{|l|}{ Mean of parameters } \\
\hline Treatment & $\begin{array}{l}\text { Fresh Grain } \\
\text { weight }\end{array}$ & $\begin{array}{l}\text { Dry Grain } \\
\text { Weight }\end{array}$ \\
\hline R1 & $2.653^{*}$ & $2.171^{*}$ \\
\hline R2 & 4.82 & 3.685 \\
\hline LSD $(5 \%)$ & $0.870^{*}$ & $0.093^{*}$ \\
\hline CV & $6.63 \%$ & $0.91 \%$ \\
\hline
\end{tabular}

$\mathrm{R} 1=$ rain fed, $\mathrm{R} 2=$ supplementary irrigation, $\operatorname{LSD}(5 \%)=$ least significant difference at $5 \%$.

$\mathrm{Cv}=$ coefficient of variation $(\%)$ and $*$ indicate significance at $5 \%$ level of probability 